\title{
First Isolation and Molecular Characterization of Bacteriophages Infecting Acidovorax citrulli, the Causal Agent of Bacterial Fruit Blotch
}

\author{
Aryan Rahimi-Midani ${ }^{1}$, Yong Seok Lee ${ }^{2}$, Se-Won Kang ${ }^{3}$, Mi-Kyeong Kim ${ }^{4}$, and Tae-Jin Choi ${ }^{1 *}$ \\ ${ }^{1}$ Department of Microbiology, Pukyong National University, Busan 48513, Korea \\ ${ }^{2}$ Department of Life Science and Biotechnology, Soonchunhyang University, Asan 31538, Korea \\ ${ }^{3}$ Biological Resources Center, Korea Research Institute of Bioscience and Biotechnology, Jeongeup 56212, Korea \\ ${ }^{4}$ Department of Clinical Laboratory Science, Gimhae College, Gimhae 50811, Korea
}

(Received on August 29, 2017; Revised on October 26, 2017; Accepted on November 2, 2017)

Bacteriophages of Acidovorax citrulli, the causal agent of bacterial fruit blotch, were isolated from 39 watermelon, pumpkin, and cucumber leaf samples collected from various regions of Korea and tested against $18 \mathrm{~A}$. citrulli strains. Among the six phages isolated, ACP17 forms the largest plaque, and exhibits the morphology of phages in the Myoviridae family with a head diameter of $100 \pm 5 \mathrm{~nm}$ and tail length of $150 \pm 5 \mathrm{~nm}$. ACP17 has eclipse and latent periods of $25 \pm 5 \mathrm{~min}$ and $\mathbf{5 0} \pm \mathbf{5}$ min, respectively, and a burst size of 120 . The genome of ACP17 is 156,281 base pairs with a $G+C$ content of $58.7 \%, 263$ open reading frames, and 4 transfer RNA genes. Blast search and phylogenetic analysis of the major capsid protein showed that ACP17 has limited homology to two Stentrophomonas phages, suggesting that $\mathrm{ACP} 17$ is a new type of Myoviridae isolated from $A$. citrulli.

Keywords : BFB, phage, watermelon

Handling Associate Editor : Oh, Chang-Sik

Bacterial fruit blotch (BFB) is a bacterial disease of many Cucurbitaceae family members caused by Acidovorax citrulli (Schaad et al., 2008) [formerly Acidovorax avenae

\footnotetext{
*Corresponding author.

Phone) +82-51-620-6367, FAX) +82-51-611-6358

E-mail)choitj@pknu.ac.kr

(c) This is an Open Access article distributed under the terms of the Creative Commons Attribution Non-Commercial License (http:// creativecommons.org/licenses/by-nc/4.0) which permits unrestricted noncommercial use, distribution, and reproduction in any medium, provided the original work is properly cited.
}

Articles can be freely viewed online at www.ppjonline.org. subsp. citrulli (Willems et al., 1992)]. After large economic losses in southwestern Indiana, USA, in the 1980s (Latin and Fane, 1990), this disease became a major economic threat to watermelon, melon, and cucumber crops in South America, Australia, and Asia (Isakeit et al., 1997; Schaad et al., 2008). In Korea, BFB was first reported in 1991 on watermelon in Gochang, Jeollabuk-do province (Song et al., 1991). Today, occasional outbreaks cause economic problems, and several lawsuits are ongoing between growers and seed companies.

BFB is known to be a seed-borne disease, and seed infestations are the result of blossom contamination with $A$. citrulli, which can localize in the embryo and endosperm tissue of seeds (Lessl et al., 2007). This bacterium causes seedling blight, necrosis of the true leaves, extensive stem necrosis, and fruit blotch. On fruit, water-soaked lesions progress through the rind, and the fruit decays and cracks. Sometimes this happens close to harvest time, causing devastating and unrecoverable losses.

Chemical treatments, such as copper-containing bactericide/fungicide application on infested fields, are ineffective (Hopkins, 1991), and there is currently no complete and monogenic resistant cultivar available. Because the disease is seed-borne, use of pathogen-free seed is a priority for disease control. Seed can be produced in areas with cool and dry climates that have a lower chance of BFB development. Seed can be treated with antibiotics and disinfectants such as streptomycin, sodium hypochlorite, and hydrochloric acid (Hopkins et al., 1996, 2003). However, as $A$. citrulli is localized under the seed coat (Lane and Latin, 1992), the control efficacy of external treatments varies widely (Hopkins et al., 2003; Rane and Latin, 1992). Treatment of the seed at $85^{\circ}$ for 3-5 days can effectively remove the pathogen, but can reduce germination (Kubota et al., 
2012)

Recently, 'phage therapy' or 'bacteriophage biocontrol' of plant disease, which are applications of bacteriophages for control of bacterial disease, is attracting public attention due to the prevalence of drug resistant bacteria and contamination of food and the environment with over-used antibiotics (Sharma et al., 2017). In this study, we isolated and characterized bacteriophages that infect $A$. citrulli for the first time, which can be used bacteriophage biocontrol of BFB.

Eighteen strains of $A$. citrulli were kindly provided by Professor Changsik Oh of Kyung Hee University and were genotyped using a PCR assay with the primers G2AcFwd (5'-CGATAGGGTTGGGTTCAAG-3'), G12AcFwd (5' -CCGAAGAGATAACACTGCATC-3') and G12AcRev (5'-ACGTACTGCCGATTTTTGC-3') (Zivanovic and Walcott, 2016). A. citrulli strains were grown on King's medium B Base (KB) at $34^{\circ} \mathrm{C}$ for $48 \mathrm{~h}$.

Samples for phage isolation were collected from 96 sites around the Korean Peninsula. Samples included soil from watermelon farms, and leaves of watermelon, pumpkin, and cucumber plants. Approximately $10 \mathrm{~g}$ of leaf or soil sample was mixed with sterilized distilled water for 30 $\min$, then centrifuged at $3000 \times \mathrm{g}$ for $20 \mathrm{~min}$ at $4^{\circ} \mathrm{C}$. The supernatant was filtered through Minisart filters (SigmaAldrich, St. Louis, MO, USA) with a $0.2-\mu \mathrm{m}$ pore size. The presence of phages was determined through a spotting assay against different $A$. citrulli strains. For the spotting assay, $300 \mu \mathrm{l}$ of exponential phase $A$. citrulli was mixed with $4 \mathrm{ml} \mathrm{KB}$ top agar, overlaid on $\mathrm{KB}$ media, and left to solidify at room temperature for 20 to $30 \mathrm{~min}$. Filtered sample water $(3 \mu \mathrm{l})$ was spotted on the solidified top agar and incubated at $34^{\circ} \mathrm{C}$ overnight. Among the 96 samples, six, including three watermelon leaves, two pumpkin leaves, and one cucumber leaf sample, were positive in the spot assay. The plaque assay was conducted three times using the wash solution described above to obtain a pure culture of bacteriophages. Plaques were picked using sterilized pipette tips with the ends cut, and were maintained in $\mathrm{SM}$ buffer (100 mM NaCl, $8 \mathrm{mM} \mathrm{MgSO}$, $50 \mathrm{mM}$ Tris-Cl). Considering the large number of samples, the percentage corresponding to six positive samples $(6.25 \%)$ is quite low. Although it has been reported that there are an average of 1.5 $\times 10^{7}$ phages per gram of soil (Ashelford et al., 2003), it is estimated that there are up to over $10^{9}$ bacterial cells in the same amount of soil (Torsvik and Øvreås, 2002). Thus, the chance of isolating phages that infect a specific bacterium is still low. One method to overcome this problem is enrichment of the phage population in samples through addition of the proper medium for the bacterial host, along with the corresponding host or a mixture of host strains, followed by incubation and phage isolation by plaque assay. In the following experiment, we performed these enrichment steps and were able to isolate several phages. On the other hand, isolation of all six phages from leaves was an unexpected result, considering the harsh conditions, such as UV radiation, present on the leaf surface. The phyllosphere is known to be the location where phages can most readily be isolated, although how the phages get there is not yet understood. It has been suggested that they originate in the soil from which the plant germinated or are deposited by insect vectors (Buttimer et al., 2017).

It is known that bacteriophages that produce larger plaques have bigger burst sizes (Abedon and Culle, 2007). If a phage is going to be used for bacteriophage biocontrol, it will be necessary to produce a large amount of phages. Therefore, we selected a phage called ACP17, which produced the largest plaques among the six phages isolated. The one-step growth curve also revealed that the eclipse and latent periods of ACP17 were $25 \pm 5 \mathrm{~min}$ and $50 \pm 5$ min, respectively and the burst size was 120 .

Phage ACP17 was amplified for EM observation and genome analysis following previously published protocols with minor modifications (Bonilla et al., 2016), including ultracentrifugation on a $\mathrm{CsCl}$ density gradient of 1.25 , 1.37 , and $1.50 \mathrm{~g} / \mathrm{ml}$. Purified phage ACP17 was placed on 300 mesh copper grid, negatively stained with $4 \%$ uracil acetate, and observed with a transmission electron microscope (H-7500, Hitachi, Ltd., Tokyo, Japan) at the Center for Research Facilities of Pukyong National University. Phage sizes were measured using the software ImageJ (https://imagej. nih.gov/ij/). EM observation showed a clear picture of a head measuring $100 \pm 5 \mathrm{~nm}$ and tail $150 \pm 5$

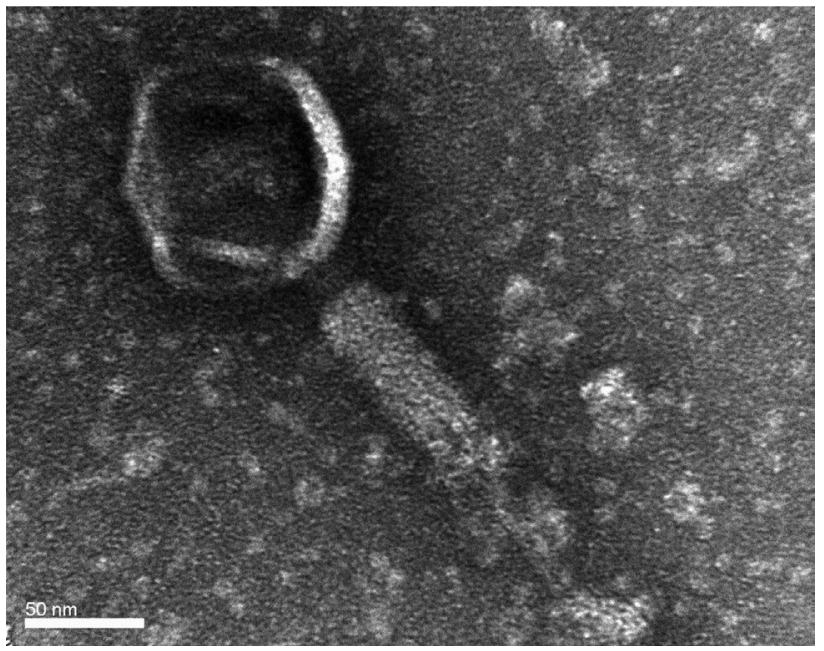

Fig. 1. Electron micrograph of ACP17 using negative staining. 
$\mathrm{nm}$ in length, indicating that phage ACP17 is a member of the family Myoviridae (Fig. 1). The family Myoviridae is composed of diverse phages with different burst sizes and infection processes. Thus, the burst size, eclipse period, and latent period are within the ranges of viruses in the Myoviridae family. For example, bacteriophage $\mathrm{J} 2$, which infects the plant pathogen Ralstonia solanacearum, belongs to the Myoviridae family and has a latent period of $60 \mathrm{~min}$ and burst size of 100-110 plaque-forming units (PFU) per infected cell showed a similar one-step growth curve to ACP17 (Bhunchoth et al., 2015).

One possible application of ACP17 is for control of BFB. There are two genotypes of $A$. citrulli, genotype I and II (Tao et al., 2009), which can be differentiated via PCR, as described above. ACP17 was tested for its lytic activity against 18 host strains; 16 of genotype I and 2 of genotype II. As shown in Table 1, ACP17 could lyse all 16 strains of genotype I and one strain of genotype II. Between the two genotypes, genotype II is the major causal agent of BFB in watermelon. Although the number of tested genotype II strains is limited, the inability of ACP17 to lyse all genotype II strains poses a problem for the application of this phage in bacteriophage biocontrol. However, more extensive investigation using more host strains, especially of genotype II, is necessary.

One concern for the use of bacteriophage biocontrol in plant disease is the stability of phage particles. Although

Table 1. Host range of phage ACP17

\begin{tabular}{ccclc}
\hline Group & No & \multicolumn{1}{c}{ Strains } & \multicolumn{1}{c}{ Host } & $\begin{array}{c}\text { Lysis activity } \\
\text { of ACP17 }\end{array}$ \\
\hline & 1 & NWB SC107 & Watermelon & + \\
& 2 & NWB SC108 & Watermelon & + \\
& 3 & NWB SC109 & Watermelon & + \\
& 4 & NWB SC111 & Watermelon & + \\
& 5 & NWB SC172 & Watermelon, fruit & + \\
& 6 & NWB SC187 & Watermelon & + \\
& 7 & NWB SC196 & Watermelon, stem & + \\
I & 8 & NWB SC201 & Watermelon & + \\
& 9 & NWB SC206 & Watermelon, stem & + \\
& 10 & NWB SC212 & cucumber, & + \\
& 11 & NWB SC238 & Watermelon, leaf & + \\
& 12 & NWB SC058 & Melon & + \\
& 13 & NWB SC076 & Watermelon & + \\
& 14 & NWB SC175 & Cucumber & + \\
& 15 & NWB SC195 & Watermelon, leaf & + \\
& 16 & NWB SC202 & Watermelon & + \\
\hline & 17 & NWB SC074 & Watermelon & - \\
& 18 & KHU & Watermelon & + \\
\hline & & & & \\
& & &
\end{tabular}

purified phage can be applied directly, it can also be mixed with other chemical components, such as antibiotics for their synergistic action (Borah et al., 2000; Frampton et al., 2012). After application, phages will face harsh conditions and the stability of phages is important for therapeutic application. Among various external physical and chemical factors that affect the survivability of bacteriophages, temperature and $\mathrm{pH}$ are crucial (Jończyk et al., 2011). The stability of ACP17 was tested at different $\mathrm{pH}$ and temperature levels. Purified ACP17 was added (approximately $4.0 \times 10^{5}$ $\mathrm{PFU} / \mathrm{ml}$ ) to SM buffer that had been adjusted to $\mathrm{pH} 2,5,6$, 7,9 , or 12 and incubated for $24 \mathrm{~h}$ at room temperature prior to plaque assays with the A. citrulli strain NWB SC196. As shown in Fig. 2, ACP17 was stable over the $\mathrm{pH}$ range of 6 to 9, but the titer decreased at $\mathrm{pH} 5$ and showed complete inactivation at $\mathrm{pH} 2$ and 12. Similarly, the stability of ACP17 was tested at different temperatures by incubating the phage (approximately $4.0 \times 10^{5} \mathrm{PFU} / \mathrm{ml}$ ) for $24 \mathrm{~h}$ at $-20,4,25,34,37,45$, and $60^{\circ} \mathrm{C}$ before performing plaque assays. The results shown in Fig. 2 reveal that ACP17 is stable at temperatures ranging from -20 to $45^{\circ} \mathrm{C}$, but is inactivated at $60^{\circ} \mathrm{C}$. These results suggest that $\mathrm{ACP} 17$ will be stable during regular mixing processes, but heating at high temperature for formulation or long-term storage at high temperature should be avoided (Gill and Hyman, 2010;
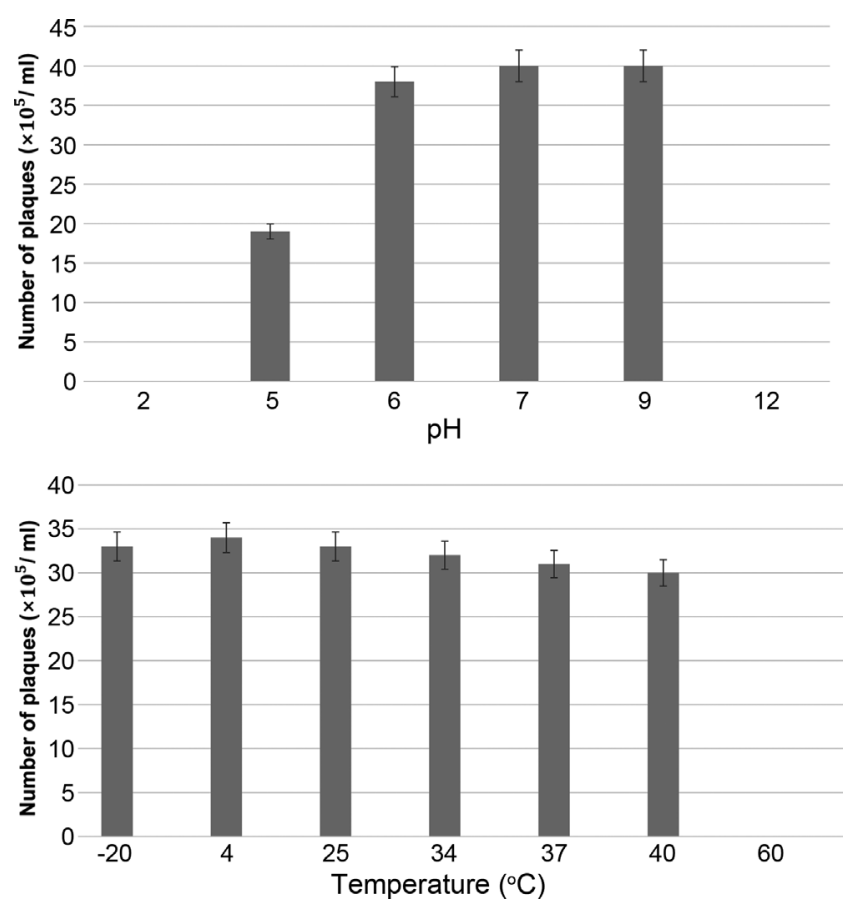

Fig. 2. Stability of ACP17 under various pH (top) and temperature (bottom) conditions analyzed by plaque assay. Results are the average of three replicates and the vertical bars indicate standard deviation. 
Lim et al., 2013).

Total nucleic acid was isolated from the purified virus and subjected to digestion with DNase, RNase, and exonuclease. As expected, nucleic acid extracted from ACP17 was digested by DNase and exonuclease but not by RNase, indicating that the nucleic acid is linear double-stranded DNA (data not shown). Genomic library construction and sequence analysis of ACP17 was performed by Teragene Korea Co., Seoul, Korea. Purified genomic DNA was randomly sheared to yield DNA fragments with an average size of 350 base pairs (bp) using a Corvaris S2 Ultrasonicator (Covaris, Inc., Woburn, MA, USA). Library preparation was performed using the Illumina TruSeq DNA PCR-free preparation kit (Illumina, Inc., San Diego, CA, USA) and sequenced on the Illumina HiSeq 4000 platform (Illumina, Inc., San Diego). Further image analysis and base calling were performed with real time analysis (RTA) 2.7.3 and bcl2fastq v2.17.1.14 (Illumina, Inc., San Diego). Normalized reads were assembled using IDBA-UD ver. 1.1.1. (Peng et al., 2012) and contigs were aligned to the NCBI nucleotide database using BLASTN with an E-value cutoff of 1e-10. Alignment results were classified taxonomically using Krona tools (Ondov et al., 2011). Bacteriophage contigs were extracted using an unshared program that we had developed. Gene models were predicted using GeneMark. hmm with Heuristic models (Besemer and Borodovsky, 1999).

Sequence analysis showed that the genome of ACP17, which is deposited in GenBank under accession number KY979132, is composed of 156,281 bp with $\mathrm{G}+\mathrm{C}$ content of $58.7 \%, 263$ open reading frames (ORF), and 4 transfer RNAs (tRNAs) (Supplementary Table 1). It also revealed

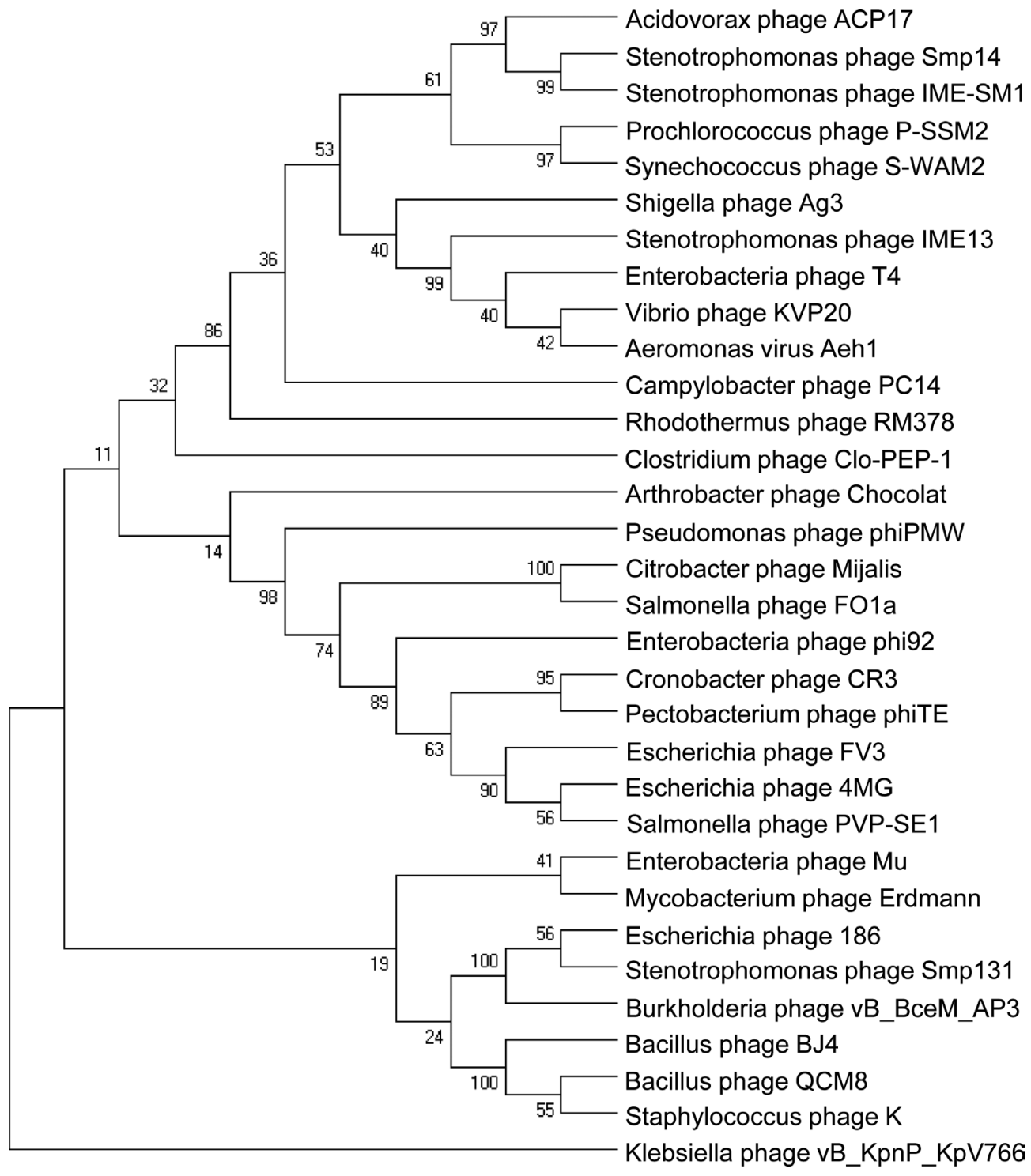

Fig. 3. Phylogenic tree based on the amino acid sequences of the major capsid proteins of selected members of Myoviridae and phage ACP17. Bar indicates the number of nucleotide substitutions per site. 


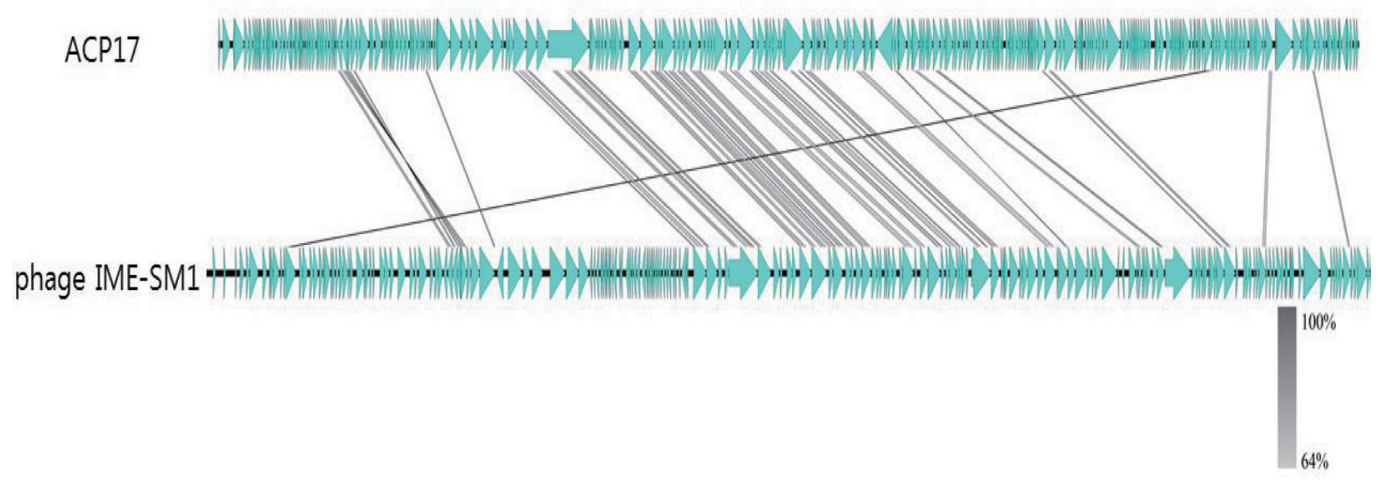

Fig. 4. Comparative analysis of phage open reading frames (ORFs) encoded by phage ACP17 and Stenotrophomonas phage IME-SM1 using using the Easyfig 9 program (http://mjsull.github.io/Easyfig/). Arrows indicate the ORFs and their orientation and lines indicate ORFs with amino acid sequence homology.

that the average length of phage genes is $578.09 \mathrm{bp}$, with a minimum length of $123 \mathrm{bp}$ and a maximum gene length of $5712 \mathrm{bp}$. Among the $263 \mathrm{ORFs}, 250$ are encoded by the plus strand and 13 by the minus strand, while 101 were predicted to encode proteins of known function such as viral structural proteins, proteins involved in virus replication, recombination, transcription, DNA modification, and virus release. In BLAST analysis, among the 101 putative proteins, only 37 and 4 showed homology to those encoded by Stenotrophomonas phage IME-SM1 and Stenotrophomonas SMP1, respectively. The high sequence homology to these two viruses was confirmed using a phylogenetic tree constructed based on the amino acid sequences of the major capsid protein. As shown in Fig. 3, ACP17 showed close relationships with these two phages.

There is no detailed information available about Stenotrophomonas phage IME-SM1, which is a member of the T4virus genus of family Myoviridae, and whose genome sequence was deposited under accession number KR560069.1. Stenotrophomonas phage SMP14 was isolated from Stenotrophomonas maltophilia, an opportunistic bacterium causing nosocomial infections. Stenotrophomonas phage SMP14 also belongs to the Myoviridae family; it has a head size of $87 \times 77 \mathrm{~nm}$, a tail of $129 \times 18 \mathrm{~nm}$, and a genome size of 160 kilobases $(\mathrm{kb})$, which makes it smaller than ACP17 but with a similar genome size. Both Acidovorax and Stenotrophomonas belong to the phylum Proteobacteria, but fall into the different classes of Gammaproteobacteria and Betaproteobacteria, respectively. Therefore, the close relationship of ACP17 to these two phages might simply indicate that ACP17 is more closely related to this virus than other known viruses, and this relationship can be resolved after more viruses similar to
ACP17 have been isolated. In fact, alignment of the ORFs encoded by ACP17 and Stenotrophomonas phage IMESM1 showed that ORFs common to both phages are a very limited component of the ORFs encoded by these two phages (Fig. 4). Therefore, we concluded that phage ACP17 is a novel phage first isolated from A. citrulli, and that it has limited homology to phages infecting Stenotrophomonas.

Despite homology to the structural proteins of Stenotrophomonas phages, the tail fiber protein of ACP17 showed the highest sequence homology to the Vibrio phage vB_VmeM-32. The ORF that encodes single-stranded DNA-binding proteins shares the highest amino acid sequence homology with that of Prochlorococcus phage PSSM5. In addition, the putative RNA ligase encoded by ACP17 showed high amino acid sequence homology with that of Ralstonia phage RSP15 and Salmonella phage SSE121. In addition, ACP17 endolysin, which can digest the bacterial cell wall (Walmagh et al., 2013), exhibits homology to Acinetobacter phage vB_AbaS_TRS, isolated from Acinetobacter baumannii (Turner et al., 2016). Therefore, considering the limited homology of proteins encoded by ACP17 to those encoded by two Stenotrophomonas phages and the small number of proteins showing homology to those of other phages, ACP17 is assumed to be a new type of phage isolated for the first time from $A$. citrulli. The application of ACP17 in bacteriophage biocontrol against $\mathrm{BFB}$ will be considered in future research.

\section{Acknowledgments}

This work was supported by a Research Grant from Pukyong National University (year 2016). 


\section{References}

Abedon, S. T. and Culler, R. R. 2007. Optimizing bacteriophage plaque fecundity. J. Theor. Biol. 249:582-592.

Ashelford, K. E., Day, M. J. and Fry, J. C. 2003. Elevated abundance of bacteriophage infecting bacteria in soil. Appl. Environ. Microbiol. 69:285-289.

Besemer, J. and Borodovsky, M. 1999. Heuristic approach to deriving models for gene finding. Nucleic Acids Res. 27:39113920.

Bhunchoth, A., Phironrit, N., Leksomboon, C., Chatchawankanphanich, O., Kotera, S., Narulita, E., Kawasaki, T., Fujie, M. and Yamada, T. 2015. Isolation of Ralstonia solanacearuminfecting bacteriophages from tomato fields in Chiang Mai, Thailand, and their experimental use as biocontrol agents. $J$. Appl. Microbiol. 118:1023-1033.

Bonilla, N., Rojas, M. I., Cruz, G. N. F., Hung, S. H., Rohwer, F. and Barr, J. J. 2016. Phage on tap-a quick and efficient protocol for the preparation of bacteriophage laboratory stocks. PeerJ 4:e2261.

Borah, P. K., Jindal, J. K. and Verma, J. P. 2000. Integrated management of bacterial leaf spot of mungbean with bacteriophages of Xav and chemicals. J. Mycol. Plant Pathol. 30:19-21.

Buttimer, C., McAuliffe, O., Ross, R. P., Hill, C., O’Mahony, J. and Coffey, A. 2017. Bacteriophages and bacterial plant diseases. Front. Microbiol. 8:34.

Frampton, R. A., Pitman, A. R. and Fineran, P. C. 2012. Advances in bacteriophage-mediated control of plant pathogens. Int. J. Microbiol. 2012:326452.

Gill, J. J. and Hyman, P. 2010. Phage choice, isolation, and preparation for phage therapy. Curr. Pharm. Biotechnol. 11:2-14.

Hopkins, D. L. 1991. Chemical control of bacterial fruit blotch of watermelon. Proc. Fla. State Hortic. Soc. 104:270-272.

Hopkins, D. L., Cucuzza, J. D. and Watterson, J. C. 1996. Wet seed treatments for the control of bacterial fruit blotch of watermelon. Plant Dis. 80:529-532.

Hopkins, D. L., Lovic, B., Hilgren, J. and Thompson, C. M. 2003. Wet seed treatment with peroxyacetic acid for the control of bacterial fruit blotch and other seedborne diseases of watermelon. Plant Dis. 87:1495-1499.

Isakeit, T., Black, M. C., Barnes, L. W. and Jones, J. B. 1997. First report of infection of honeydew with Acidovorax avenae subsp. citrulli. Plant Dis. 81:694-694.

Jończyk, E., Kłak, M., Międzybrodzki, R. and Górski, A. 2011. The influence of external factors on bacteriophages. Folia Microbiol. (Praha) 56:191-200.

Kubota, M., Hagiwara, N. and Shirakawa, T. 2012. Disinfection of seeds of cucurbit crops infested with Acidovorax citrulli with dry heat treatment. J. Phytopathol. 160:364-368.

Latin, R. X. and Rane, K. K. 1990. Bacterial fruit blotch of watermelon in Indiana. Plant Dis. 74:331-335.

Lessl, J. T., Fessehaie, A. and Walcott, R. R. 2007. Colonization of female watermelon blossoms by Acidovorax avenae ssp. citrulli and the relationship between blossom inoculum dosage and seed infestation. J. Phytopathol. 155:114-121.

Lim, J. A., Jee, S., Lee, D. H., Roh, E., Jung, K., Oh, C. and Heu, S. 2013. Biocontrol of Pectobacterium carotovorum subsp. carotovorum using bacteriophage PP1. J. Microbiol. Biotechnol. 23:1147-1153.

Peng, Y., Leung, H. C., Yiu, S. M. and Chin, F. Y. 2012. IDBAUD: a de novo assembler for single-cell and metagenomic sequencing data with highly uneven depth. Bioinformatics, 28:1420-1428.

Ondov, B. D., Bergman, N. H. and Phillippy, A. M. 2011. Interactive metagenomic visualization in a Web browser. BMC Bioinformatics, 12:385.

Rane, K. K. and Latin, R. X. 1992. Bacterial fruit blotch of watermelon: association of the pathogen with seed. Plant Dis. 76:509-512.

Schaad, N. W., Postnikova, E., Sechler, A., Claflin, L. E., Vidaver, A. K., Jones, J. B., Agarkova, I., Ignatov, A., Dickstein, E. and Ramundo, B. A. 2008. Reclassification of subspecies of Acidovorax avenae as A. Avenae (Manns 1905) emend., A. cattleyae (Pavarino, 1911) comb. nov., A. citrulli Schaad et al., 1978) comb. nov., and proposal of $A$. oryzae sp. nov. Syst. Appl. Microbiol. 31:434-446.

Sharma, S., Chatterjee, S., Datta, S., Prasad, R., Dubey, D., Prasad, R. K. and Vairale, M. G. 2017. Bacteriophages and its applications: an overview. Folia. Microbiol. 62:17-55.

Song, W. Y., Kim, H. M., Son, I. Y. and Kang, Y. K. 1991. Pseudomonas pseudoalcaligenes subsp. citrulli: The causal agent of bacterial fruit blotch rot on watermelon. Korean J. Plant Pathol. 7:177-18.

Tao, C., Guo-Liang, Q., Xiao-Li, Y., Jun-Yi, M., Bai-Shi, H. and Feng-Quan, L. 2009. Detection of a quorum sensing signal molecule of Acidovorax avenae subsp. citrulli and its regulation of pathogenicity. Chin. J. Agric. Biotechnol. 6:49-53.

Torsvik, V. and Øvreås, L. 2002. Microbial diversity and function in soil: from genes to ecosystems. Curr. Opin. Microbiol. $5: 240-245$.

Turner, D., Wand, M. E., Sutton, J. M., Centron, D., Kropinski, A. M. and Reynolds, D. M. 2016. A viable prophage isolated from Acinetobacter baumannii strain A118. Genome announc. 4:e01051-16.

Walmagh, M., Boczkowska, B., Grymonprez, B., Briers, Y., Drulis-Kawa, Z. and Lavigne, R. 2013. Characterization of five novel endolysins from Gram-negative infecting bacteriophages. Appl. Microbiol. Biotechnol. 97:4369-4375.

Willems, A., Goor, M., Thielemans, S., Gillis, M., Kersters, K. and De Ley, J. 1992. Transfer of several phytopathogenic Pseudomonas species to Acidovorax as Acidovorax avenae subsp. avenae subsp. nov., comb. nov., Acidovorax avenae subsp. citrulli, Acidovorax avenae subsp. cattleyae, and Acidovorax konjaci. Int. J. Syst. Evol. Microbiol. 42:107-119.

Zivanovic, M. and Walcott, R. R. 2016. Further characterization of genetically distinct groups of Acidovorax citrulli strains. Phytopathology 107:29-35. 